\title{
METALLOTHIONEINS INVOLMENT IN THE PATHOGENESIS OF SYNOVIAL TISSUE INFLAMMATION IN RATS WITH ACUTE GONARTHRITIS
}

\author{
T. R. MATSKIV ${ }^{1,2}$, D. V. LYTKIN ${ }^{3}$, S. K. SHEBEKO ${ }^{3}$, V. V. KHOMA², \\ V. V. MARTYNIUK ${ }^{2}$, L. L. GNATYSHYNA ${ }^{1,2}$, O. B. STOLIAR ${ }^{2 \bowtie}$ \\ ${ }^{1}$ I. Horbachevsky Ternopil National Medical University, \\ Department of General Chemistry, Ternopil, Ukraine; \\ ${ }^{2}$ Ternopil Volodymyr Hnatiuk National Pedagogical University, \\ Department of Chemistry and Methods its Teaching, Ternopil, Ukraine; \\ ${ }^{3}$ National University of Pharmacy, Educational and Scientific Institute \\ of Applied Pharmacy, Kharkiv, Ukraine; \\ 凶e-mail: Oksana.Stolyar@tnpu.edu.ua
}

Received: 02 June 2021; Accepted: 22 September 2021

Zinc (Zn) is involving in the suppressing of inflammation. However, its functionality in the knee joint under the gonarthritis (GA) is not elucidated. The aim of this study was to investigate the participation of $\mathrm{Zn}$-buffering and stress responsive proteins metallothioneins (MTs) in the pathogenesis of the synovial tissues under the experimental acute GA. The inflammation was induced in rats by intra-articular administration of carrageenan. The concentrations of MTs total protein (MTSH), Zn-bound protein (Zn-MTs), total Zn concentration in the tissue, the indexes of oxidative stress and cholinesterase activity were determined. The level of sialic acids was indicated in the blood serum. The enhancing of sialic acids concentration by $42 \%$ and cholinesterase depletion confirmed the pathology. In the animals with GA, total level of Zn in the tissue was correspondent to control. However, the MTSH and Zn-MT levels were elevated (by 79 and $46 \%$ respectively). This disproportionate rate can be due to partial oxidation of thiols. The superoxide dismutase activity was elevated, radical scavenging activity and protein carbonylation were correspondent to control, but the levels of catalase, glutathione-S-transferase and glutathione were decreased by $28-44 \%$, and lipid peroxidation (TBARS) was increased by 59\% compared to control group. Principal Component Analysis confirmed the strong interrelations between MTs and peroxide-related oxidative stress indexes. This preliminary study provides the basis for the understanding of the reason for Zn imbalance in the acute GA as the result of the impairment of thiol redox balance and proposes these biomarkers for the evaluation of knee joint pathologies.

Keywords: gonarthritis, metallothioneins, Zinc, oxidative stress.

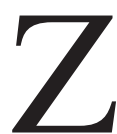

inc (Zn) homeostasis is essential for immune function. There are plural data witnessing a continuous deficiency of $\mathrm{Zn}$ in serum and plasma of patients with inflammation [1,2]. Metallothioneins (MTs) are low molecular weight, thermostable intracellular proteins ubiquitous in the animal world [2]. The unique function of MTs is devoted to metal (in the mammals, mainly $\mathrm{Zn}$, and also copper and cadmium) buffering and distribution within the cells [3]. However, due to abundant cystein content (about 30\% in the composition), they also can be re- garded as stress inducible antioxidants. Therefore, Zn deficiency and disturbing of its sequestration with the participation of MTs can play important function under these disorders. Particularly, it was proved that intracellular and extracellular MTs have different impact on T-cell activation and proliferation [4]. Of note, the extracellular MTs were found to participate in the regulation of immune responses. Gonarthritis (GA) is an inflammation of the knee joint of different etiology that most often leads to the joint tissue degeneration [5]. However, to the best of 
our knowledges, the ability to accumulate Zn-MTs in the knee joint under the GA was not investigated. Nevertheless, it was shown the suppressive effect of the repeated administration of MTs on its severity [4].

The aim of the research was to elucidate the presence of MTs in the joint tissues under the GA model and their possible relation to the $\mathrm{Zn}$ distribution and oxidative stress response. The goal was dissolved throw the analysis of the total concentration of MTs in the joint tissue and their Zn-bound form (Zn-MTs), total Zn concentration in the tissue and the indication of the oxidative stress response. The level of inflammation was evaluated from the concentration of sialic acids in the blood serum. To elucidate the relations between the indices, Principal Component Analysis was accomplished.

\section{Materials and Methods}

Chemicals and methodology used are given in detail in the Supplementary materials. All reagents were of the reagent grade or higher (S1 Appendix). They were obtained from Sigma-Aldrich (USA), Synbias (Ukraine) or SpineLab (Ukraine).

Experimental study was performed using 20 randomly-selected male Wistar albino rats 3-4 month old weighing 200-220 g, which were obtained from the vivarium of Educational and Scientific Institute of Applied Pharmacy (National University of Pharmacy, Kharkiv, Ukraine). The animals received standard rat diet and water ad libitum. The rats were housed under standard laboratory conditions in a well-ventilated room at $25 \pm 1^{\circ} \mathrm{C}$ and with a relative humidity of $55 \pm 5 \%$ with a regular $12 \mathrm{~h}$ light/12 h dark cycle. All studies were conducted in accordance with the EU Council Directive 2010/63/EU dated 22 September 2010 on the protection of animals used for scientific purposes. The experimental protocols were approved by the Bioethics Commission of the National University of Pharmacy (Approval No. 5 of March, 25, 2021).

All animals were randomly divided into 2 experimental groups as follows: Group 1 - intact control (healthy rats receiving vehicle, $n=10$ ); Group 2 - control pathology (untreated rats with carrageenan-induced GA, $n=10$ ).

At the beginning of the experiment all animals of intact control group received $25 \mu 1$ of vehicle (sterile saline) in to the both knees. Simultaneously, in rats of the control pathology group inflammation was induced in both knees by $25 \mu 1$ single intra-ar- ticular injection of 2\% carrageenan, previously dissolved in sterile saline. Day 7 time-point was used because at this time-point GA induced changes in knee joint pathology are evident [6]. The animals were sacrificed in $\mathrm{CO}_{2}$-box at the end of experiment. Blood samples were collected from the inferior vein cava and centrifuged at $1500 \mathrm{~g}$ at $+4^{\circ} \mathrm{C}$ for $10 \mathrm{~min}$ utes using refrigerated centrifuge Eppendorf 5702R (Eppendorf, Germany).

For oxidative stress indexes, joint tissues were homogenized $(10 \% \mathrm{w} / \mathrm{v})$ in $0.1 \mathrm{M}$ phosphate buffer, $\mathrm{pH} 7.4$, containing $100 \mathrm{mM} \mathrm{KCl}$ and $1 \mathrm{mM}$ EDTA, as well as $0.1 \mathrm{mM} 0.1 \mathrm{mM}$ phenylmethylsulfonyl fluoride (PMSF) for proteolysis inhibition. Homogenates were centrifuged at $6,000 \mathrm{~g}$ for $10 \mathrm{~min}$, and the resulting supernatant was kept at $-80^{\circ} \mathrm{C}$. For the analysis of cholinesterase (ChE), the $10 \% \mathrm{w} / \mathrm{v}$ homogenate was prepared in the same buffer without PMSF and analyzed within the same day. For the MTs assays, homogenates were prepared separately. The protein concentration was assayed in the $6,000 \mathrm{~g}$ supernatant according to the method of Lowry et al. (1951), using bovine serum albumin as the protein standard.

Concentration of metallothionein protein (MTSH) was assessed using 5,5'-dithio-bis(2-nitrobenzoic acid) (DTNB) reduction method after the ethanol/chloroform extraction from tissue homogenate [7]. Reduced glutathione (GSH) was utilized as a reference standard. The MTSH concentration was expressed as nmol of protein per $g$ fresh weight (FW). For the evaluation of Zn concentration in metallothioneins (Zn-MT), these proteins were isolated as the thermostable proteins by size-exclusion chromatography on Sephadex G-50 [8]. For each replicate, total of $350 \mathrm{mg}$ from five animals were combined. The supernatant of homogenate in $10 \mathrm{mM}$ Tris-HCl buffer, $\mathrm{pH}$ 8.0, $10 \mathrm{mM} \beta$-mercaptoethanol and $0.1 \mathrm{mM}$ PMSF was incubated under the $85^{\circ} \mathrm{C}$ for $5 \mathrm{~min}$ and subsequently centrifuged at $14500 \mathrm{~g}$ for $45 \mathrm{~min}$ at $4^{\circ} \mathrm{C}$. The obtained supernatant was applied to the size-exclusion chromatography on Sephadex G-50. Low weight (approximately $6 \mathrm{kDa}$ ) fractions with high absorbance at $254 \mathrm{~nm}$ and high D254/ D280 density ratio were identified as putative MTscontaining peak and pooled (to the total of $10 \mathrm{ml}$ ) for the $\mathrm{Zn}$ determination.

The concentration of $\mathrm{Zn}$ was measured in the joint tissue ( $\mathrm{Zn} \mathrm{t}$ ) and in the pooled MT-containing fractions (Zn-MT) utilizing the reaction of the complexation of $\mathrm{Zn}$ (II) with $0.6 \mathrm{M}$ 2-(5-bromo- 
2-pyridylazo)-5-[N-propyl-N-(3-sulfopropyl) amino] phenol disodium salt dihydrate (5-Br-PAPS) in carbonate buffer ( $\mathrm{pH} 8.9$ ) after the digestion of the samples with $\mathrm{HNO}_{3}$ [10]. Zn concentration was evaluated from the absorbance of the metal-5-Br-PAPS complex at $560 \mathrm{~nm}$. Detection limit was $0.1 \mu \mathrm{g} \cdot \mathrm{g}^{-1} \mathrm{FW}$. Quality control was performed by method of Standard Addition. Metal concentration in the tissue and MTs was expressed as nmol $\mathrm{g}^{-1} \mathrm{FW}$.

Total antioxidant (ABTS $^{-+}$radical scavenging) capacity (TAC) was determined according to Re et al. (1999) [10]. $\mathrm{ABTS}^{-+}$radicals were pregenerated by potassium persulfate. The ascorbic acid was used as reference compound. The reduction in absorbance was recorded at $734 \mathrm{~nm}$. The result was compared with blank (only ABTS $^{*+}$ solution). Superoxide dismutase (SOD, EC 1.15.1.1) activity was determined spectrophotometrically by measuring its ability to inhibit the photoreduction of nitro bluetetrazolium (NBT) according to the method of Beauchamp and Fridovich (1971) [11]. The reduction of NBT was measured at $560 \mathrm{~nm}$. The results were expressed as SOD units per mg of protein (one unit of SOD is defined as the amount of enzyme that causes $50 \%$ inhibition of NBT reduction. Catalase (CAT, EC 1.11.1.6) activity was quantified by monitoring the degradation of $\mathrm{H}_{2} \mathrm{O}_{2}$ according to Aebi (1974) [12] at $240 \mathrm{~nm}$ and referred to the protein content. Glutathione S-transferase (GST, EC 2.5.1.18) activity was assayed using GSH and 1-chloro-2,4-dinitrobenzene (CDBN) as the substrate [13] and expressed as nmol $\mathrm{min}^{-1} \cdot \mathrm{mg}^{-1}$ soluble protein. Total glutathione concentration (GSH) was quantified by the glutathione reductase recycling assay [14] in the protein-free extract of homogenate using DTNB. Concentration was expressed as nmol g-1 $\mathrm{FW}$.

The products of lipid peroxidation and protein carbonyls were determined in the same sample of homogenate after the sedimentation of proteins in sulfosalicylic acid. The supernatant was used for the determining of the production of thiobarbituric acid-reactive substances (TBARS) [15]. A molar extinction coefficient of $1.56 \cdot 10^{5} \mathrm{M}^{-1} \cdot \mathrm{cm}^{-1}$ was used, and the concentrations were expressed as nmol per g FW. Protein carbonyls (PC) were determined as an index of protein oxidation in the sediment of homogenate after its centrifugation by reaction with 2,4-Dinitrophenylhydrazine [16]. The concentration of carbonyls was expressed as nmol PC per g FW.

Cholinesterase (ChE, EC 3.1.1.7) activity was determined immediately after sampling in the 10\% w/v homogenate according to the colorimetric method of Ellman et al. (1961) [17]. Acetylcholine iodide was used with DTNB as the thiol indicator. Enzyme activity was referred to the protein content. The level of sialic acids ( $\mathrm{SiA}$ ) in the serum was assayed by standard commercial kit "Sialic acids" (SpineLab, Ukraine) for the indication of joint tissues destruction severity. The content was determined spectrophotometrically by half-automatically biochemical analyzer MapLabPlus (BSI, Italy).

Results were expressed as mean \pm SD. Zn-MTs analysis was repeated in four replicates for each of two independent samples each combined from five individuals in the group, resulting in $n=8$ for each group. For all other traits, sample size was eight from eight individuals. Shapiro-Wilk test was used for the assessment of normality. Data were analyzed with parametric Student's $t$-test significant at $P<0.05$. Principal component analysis (PCA) was performed to assess the relations between measured parameters utilizing rotation method Varimax. The adequacy of data was evaluated based on the value of KMO and Bartlett test of sphericity. The IBM SPSS Statistics version 26 software for Windows were used for calculations.

\section{Results and Discussion}

By the size-exchange chromatography we obtained only one peak, whereas typical profile of the thermostable proteins from the metabolic active tissues is represented by two peaks [18]. The low molecular mass, thermostability, and UV absorption spectrum with the band at $\sim 254 \mathrm{~nm}$, intrinsic for metal-thiolate clusters, and absence of the band at the $280 \mathrm{~nm}$ indicate the distinctive features of MTs (Fig. 1, A, B) [2, 8]. In the GA-group, the chromatographic profile of thermostable proteins contained the additional peak with higher molecular mass, whereas the MTs-related peak became more abundant. Nevertheless, the UV-spectrum of this peak was corresponding to control.

The concentrations of MTSH and Zn-MT were elevated in the GA-group compared to control (Fig. 2). Particularly, the level of MTSH was increased by $79 \%$. The level of Zn-MT was increased too, but to a lesser extend (by 46\%). Correspondingly, the part of insufficiently metalated MT in the total pool of this protein increased in the GA-group compared to the control. The total Zn concentration in the tissue of GA-group was not significantly different compared to the control group (Fig. 2, C). Conse- 
$A$

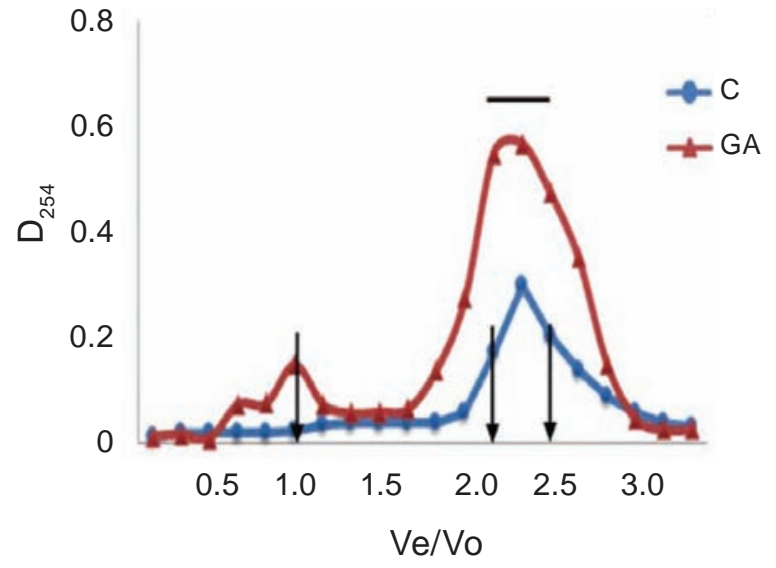

B

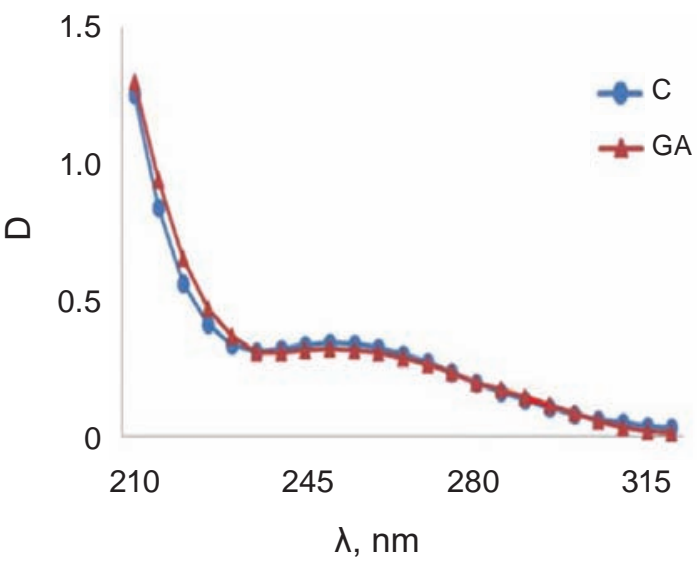

Fig. 1. The elution profile (A) and UV-spectra (B) of the thermostable proteins from the knee joint tissues of rats with acute gonarthritis and control animals obtained by chromatography on Sephadex G-50. In Fig. 1,A: arrows highlight the elution volume of markers: $67.0 \mathrm{kDa}, 12.3 \mathrm{kDa}, 5.8 \mathrm{kDa}$ appropriate to 1.0, 2.17, $2.5 \mathrm{Ve} /$ Vo correspondingly; Ve, elution volume; Vo, void volume of the column; arrow indicate the elution volume of standard metallothionein from rabbit liver

$\boldsymbol{A}$

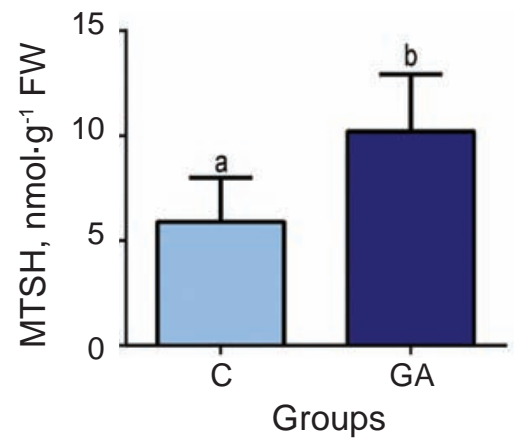

B

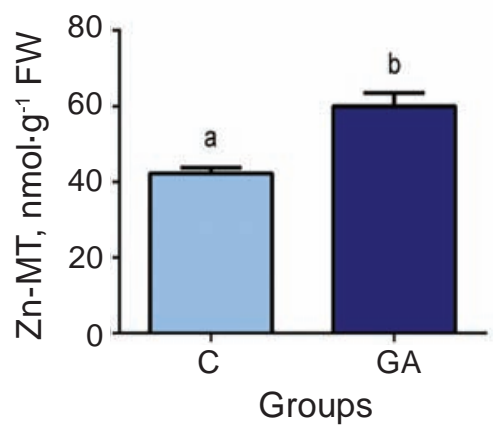

C

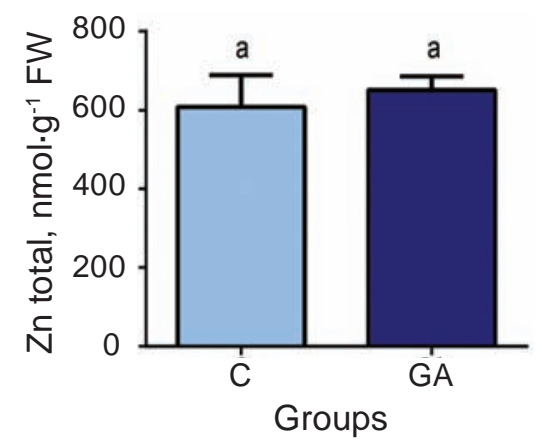

Fig. 2. Concentrations of metallothioneins (A), metallothionein-related $\mathrm{Zn}(\mathbf{B})$, and total $\mathrm{Zn}(\mathbf{C})$ in the knee joint tissues of rats with acute gonarthritis and control animals. Data are presented as means $\pm S D(n=8)$. Different letters above the columns indicate significantly different values $(P<0.05)$

quently, MTs bound rather high amount of Zn, about $6.95 \%$ of total $\mathrm{Zn}$ in the tissue in the control animals and $9.21 \%$ in the experimental group.

The evaluation of the oxidative stress indexes revealed the misbalance of the antioxidant activities (Fig. 3). SOD activity was increased by about twice and the TAC and PC levels did not differ from the control value. In opposite, the levels of CAT, GSH and GST were lower by 28-44\%.The level of TBARS was higher by $59 \%$ than control value.

The severity of knee joint tissue damaging was confirmed successfully from the strong elevation of sialic acids level in the serum (by 42\%) compared to control group (Fig. 4, A). It was also shown the decreased by $30 \%$ cholinesterase activity in the knee joints of the rats with GA (Fig. 4, B).
Principal Component Analysis was applied to the datasets in order to identify relations between indices. Fig. 5 illustrates the score plot (component 1 vs. component 2) and shows a good distribution of the variables. Two first components explained $63.9 \%$ of the total variance of dataset. Eight indexes were highly related to the first principal component (PC1): Zn-MT, MTSH, SiA and TBARS in the positive part of the axis, and set of GST, ChE, CAT, GSH - in its negative part with loading $>|0.52|$.

In this study, the presence of MTs in the joint tissue and increase of their concentration in the GAgroup attests their involving in the response to inflammation. It was proposed that the functions of MTs within the cells and outside of cells can be different. Whereas in the cells they serve as the reser- 
$A$

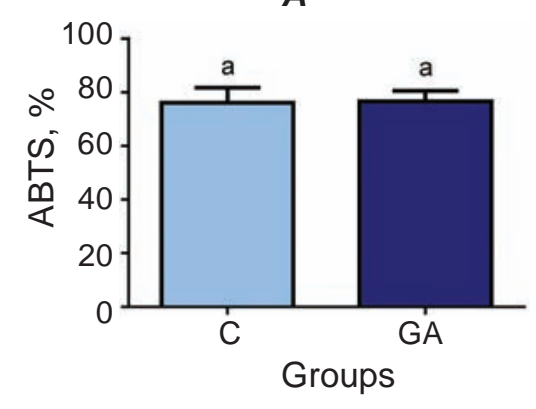

C

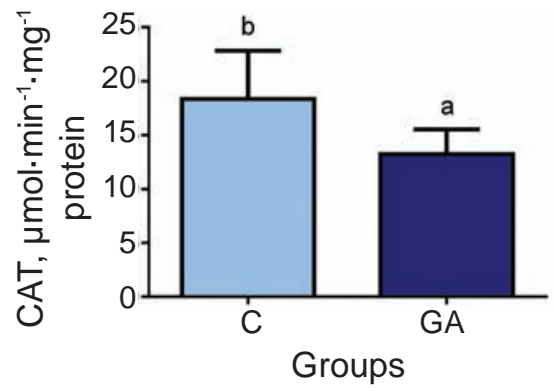

$B$

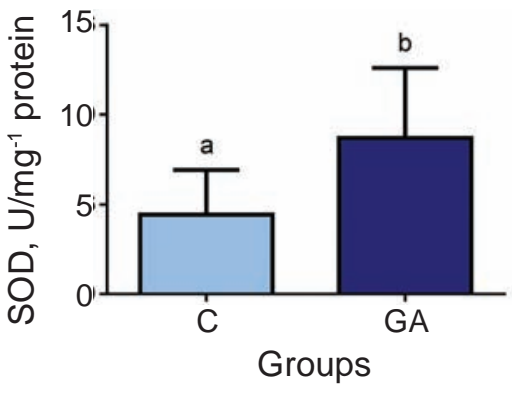

D

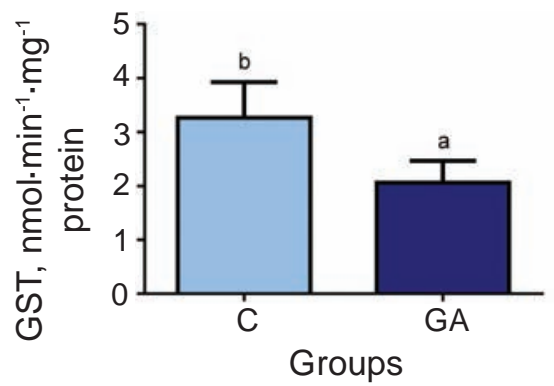

$E$

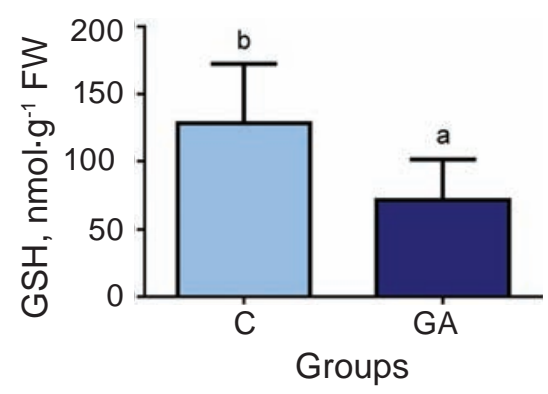

$\boldsymbol{F}$

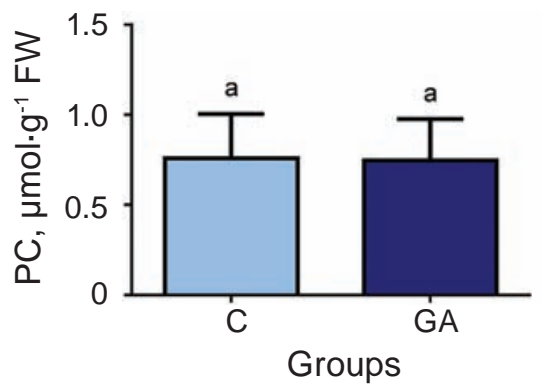

G

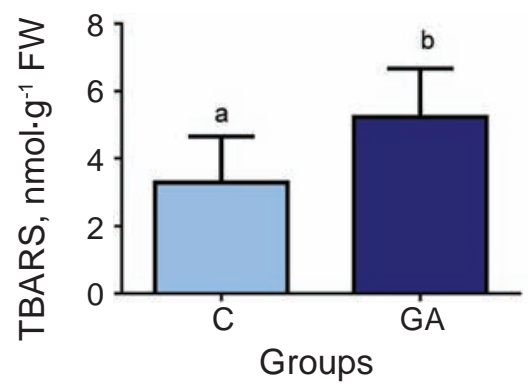

Fig. 3. Oxidative stress parameters in the knee joint tissues of rats with acute gonarthritis (GA) and control animals (C): $\boldsymbol{A}$ - total antioxidant capacity (ABTS); $\boldsymbol{B}$ - superoxide dismutase activity; $\boldsymbol{C}$ - catalase activity; $\boldsymbol{D}$ - glutathione S-transferase activity; $\boldsymbol{E}$ - GSH concentration; $\boldsymbol{F}$ - protein carbonyls production (PC); $\boldsymbol{G}$ lipid peroxidation (TBARS) production. Data are presented as means $\pm S D(n=8)$. Different letters above the columns indicate significantly different values $(P<0.05)$.

voir for metals, extracellular protein can represent a "danger signal" of cell death or leakage [19]. Indeed, we can track two directions of MTs functionality in the joint tissue under the GA pathology. Firstly, this is the increased MT-SH and Zn-MT levels, probably in the result of the elevated MTs expression. The link between the expression of MTs genes and interleukin-1 under the inflammation was reported earlier [20]. This defensive mechanism can support the $\mathrm{Zn}$ storage within the cells under the inflammation, which is associated with low intracellular $\mathrm{Zn}$ ion bioavailability [21]. Moreover, it was shown that a local elevation of MT-1 expression intraarticularly significantly suppressed the synovial inflammation and pathologic symptoms in collagen-induced arthritis and shifted the balance of the lymphocyte subsets with opposing actions [1, 4]. The PCA (Fig. 5) indicates the key place of Zn-MTs in the biochemical events in this tissue and its correspondence to the severity of inflammation determined from the level of sialic acids in the plasma.

Second direction of the MTs functionality under the GA model reflects their involving in the oxidative stress response. Redox control by MTs occurs mainly via scavenging reactive oxygen species (ROS) because MT-SH are highly sensitive to the oxidation [3]. The juxtaposition of the obtained results indicates that the increase of the MTs con- 


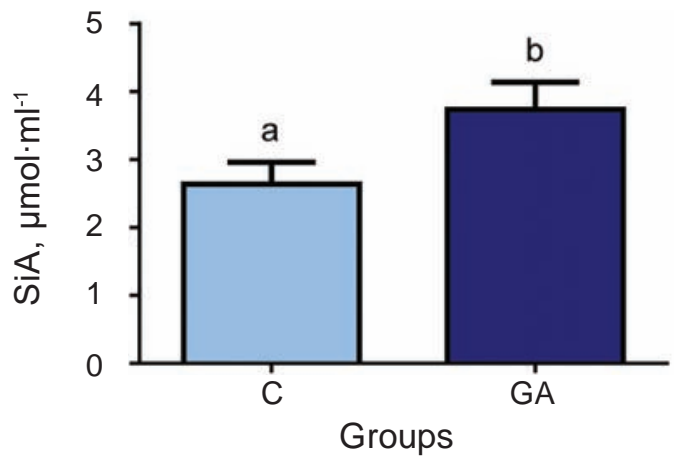

B

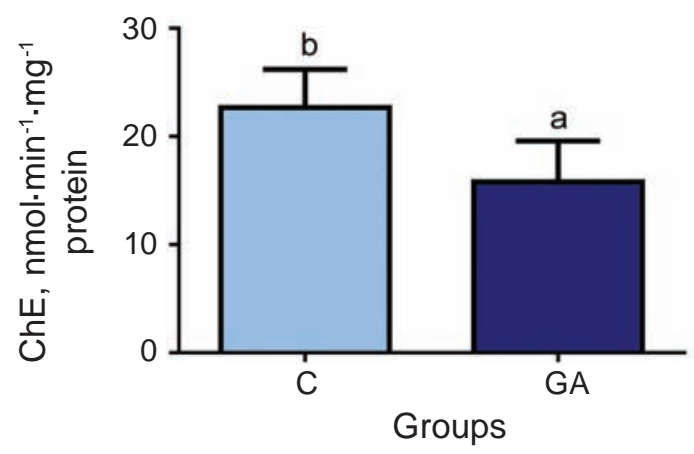

Fig. 4. Sialic acids (SiA) concentration in the blood plasma (A) and cholinesterase activity in the knee joint (B) of rats with acute gonarthritis and control animals. Data are presented as means $\pm S D(n=8)$. Different letters above the columns indicate significantly different values $(P<0.05)$.

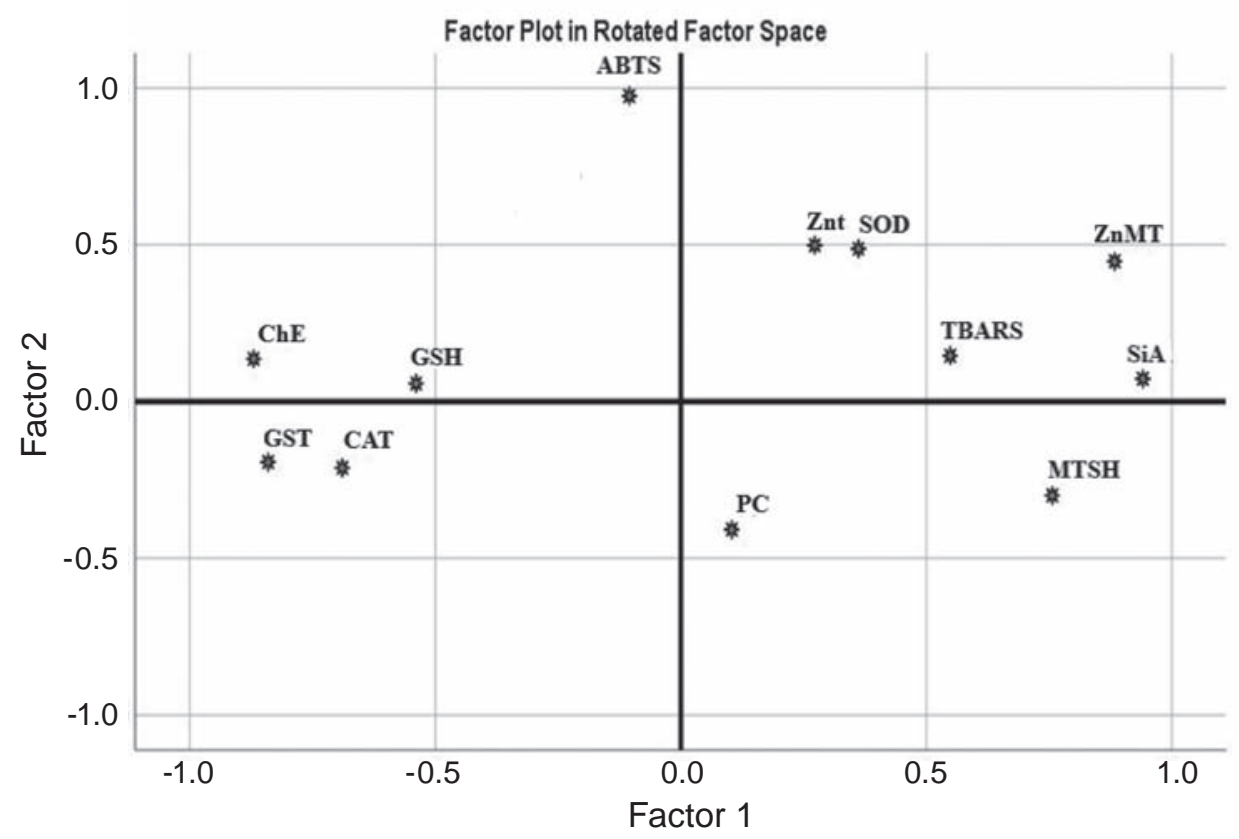

Fig. 5. The results of Principal Component Analysis (PCA) applied to reveal the relations between measured parameters

centration in the GA-model was accompanied by their underloading by $\mathrm{Zn}$. This imbalance can be explained by the partial oxidation of the thiols in MTs. The particular interrelations of MTSH and Zn-MTs and misbalance in the oxidative stress manifestations are evident from the PCA (Fig. 5). The elevated SOD activity induced by inflammation can provide the scavenging of ROS and protect from the protein oxidation in the tissue under the acute inflammation. Such a temporal response to inflammation was reported [21], whereas the chronic inflammation is known to cause the opposite manifestation, the inhibition of SOD activity [22]. It was reported the higher antioxidant levels in rheumatoid arthritis patients than in healthy controls; however, they were insufficient to prevent oxidative damage [23]. In any case, this set of oxidative stress indexes did not correlated with MTs.

The second set of the oxidative stress indexes (Fig. 5) gives the evidence that the loss of $\mathrm{Zn}$ binding activity by MTs is related to the peroxidedependent stage of the ROS activities. This set included CAT, GST, GSH, TBARS, MTs, Zn-MT and SA. According to this tight inter-relation, the 
deep decrease of the CAT, GST, GSH levels is directly related to the MTs and inflammation manifestations. Indeed, the misbalance of the antioxidant defense caused by the elevated SOD and decreased CAT activities evidently induces the accumulation of $\mathrm{H} 2 \mathrm{O} 2$ [24]. Similar antioxidant disorders with the unchanged or elevated SOD activity, decreased CAT and GST levels and increased TBARS production in the blood were reported for the patients with rheumatoid arthritis and at the early stage of Alzheimer's Disease [25]. Cysteine residues are particularly vulnerable to $\mathrm{H}_{2} \mathrm{O}_{2}$ [26], and thiols in the MTs can be particularly easy oxidized to disulphide bridges, because their redox potential is very low $[2,3]$. The decrease of GSH level can also cause the weakness of the stabilization of the MTs-related thiols. GSH depletion increased the sensitivity of the hepatic stellate cells to $\mathrm{H}_{2} \mathrm{O}_{2}$-induced necrosis [24]. Hence, the oxidative stress during the inflammation facilitates release of metals from the thiolate clusters in MTs promoting their distribution among the cellular targets and the utilizing of MTs in the ROS scavenging [20].

Two MTs indexes, MTSH and Zn-MT, are seldom compared in the same study $[2,3,18]$. However, only this combination gives the possibility to indicate the insufficient metalation of MTs. Besides, different other Zn-binding proteins were shown to be metalated insufficiently in the Zn-deficient cells [27].

In the explored model of GA, the elevated level of sialic acids in the blood plasma confirmed the severity of inflammation. The depletion of $\mathrm{ChE}$ activity is also the sign of synovial tissue injury. While ChE is mostly known for degrading acetylcholine in the neural synapses, it is also involved in regulating bone development and remodeling. Pharmacological suppression of ChE has been associated with increased survival under the inflammation, decreasing the synthesis and release of inflammatory cytokines from activated macrophages [28]. Importantly, the ChE activity highly negatively correlated with MTs-related indexes.

Within the framework of this study, we would like to formulate a hypothesis about the possible molecular function of MTs in the pathogenesis of inflammatory and degenerative-dystrophic diseases of the joint tissue. MTs are known for being intracellular proteins $[2,3]$. However, most acute inflammatory conditions are associated with cell cytolysis, which allows intracellular proteins to enter the extracellular area and continue to perform their functions there. We suggest that the important evolutionary place of MTs is outlined as follows. Under conditions of an acute inflammatory-destructive process, they are able to enter the synovial fluid and accumulate $\mathrm{Zn}$ themselves, thereby turning off the activity of proteins such as Zn-dependent metalloproteinases, the importance of which in pathogenesis of joint diseases is undeniable [29]. This hypothesis was made based on the analysis of some scientific works [30], although it was not formulated by the authors. This assumption is also indirectly confirmed by our data as an increase in the absolute amount of Zn-MT with a constant value of total $\mathrm{Zn}$ in the joint homogenate against the background of acute GA. However, our data do not provide a precise answer to this question. Confirmation of such a molecular mechanism of MTs requires further in-depth studies.

To summarize, we discovered the MTs in the knee joints of rats and detected the change of their properties under the GA pathology. All the obtained data confirm the importance of $\mathrm{Zn}$ involving in the response under the inflammation in the tight relation with the second phase of ROS scavenging and inflammation biomarker. Moreover, under the model of acute inflammation, the weakness of MTs to bind Zn due to possible oxidative injury can provide the decisive input in the response to inflammation.

This preliminary study provides the basis for the understanding of the $\mathrm{Zn}$ imbalance in the acute GA and the selection of biochemical markers for the evaluation of adequate pharmacological treatment of knee joint pathologies.

Conflict of interest. Authors have completed the Unified Conflicts of Interest form at http://ukrbiochemjournal.org/wp-content/uploads/2018/12/ coi_disclosure.pdf and declare no conflict of interest.

Funding. This work has been granted by the Ministry of Education and Science of Ukraine to Oksana Stoliar (Ukrainian-Lithuanian R\&D Project No M19/2020). 


\section{ЗАЛУЧЕННЯ МЕТАЛОТІОНЕЇНІВ У ПАТОГЕНЕЗ ЗАПАЛЕННЯ СИНОВІАЛЬНОЇ ТКАНИНИ В ЩУРІВ ІЗ ГОСТРИМ ГОНАРТРИТОМ}

\author{
T. Р. Мацьків 1,2 , Д. В. Литкін \\ С. К. Шебеко , В. В. Хома ${ }^{2}$, \\ В. В. Мартинюк ${ }^{2}$, Л. Л. Гнатишина ${ }^{1,2}$, \\ О. Б. Столяр ${ }^{2 \varpi}$
}

\footnotetext{
${ }^{1}$ Тернопільський національний медичний університет імені І.Я. Горбачевського, кафедра загальної хімії, Україна;

${ }^{2}$ Тернопільський національний педагогічний університет імені Володимира Гнатюка, кафедра хімії та методики іiї навчання, Україна; ${ }^{3}$ Національний фармацевтичний університет, навчально-науковий інститут прикладної фармації, Харків, Україна; e-mail: Oksana.Stolyar@tnpu.edu.ua
}

Цинк (Zn) залучений у пригнічення запальних процесів, проте його участь за гонартриту (ГА) у колінному суглобі не з'ясована. Метою роботи було дослідити роль $\mathrm{Zn}$-буферних та стрес-реактивних протеїнів металотіонеїнів (МТ) у функціональній активності синовіальних тканин за експериментального гострого ГА. Запалення індукували внутрішньосуглобовим введенням щурам карагенану. У синовіальній тканині визначали концентрацію загального (MTSH) та Zn-вмісного (Zn-MTs) MT, вміст Zn, показники окисного стресу та активність холінестерази. Рівень сіалових кислот оцінювали в сироватці крові. Розвиток патології засвідчили зростанням рівня сіалової кислоти на 42\% та пригніченням холінестеразної активності. У тварин із ГА загальний рівень Zn у тканині відповідав контролю. Проте рівень як MTSH, так i Zn-MT зростав, але непропорційно (на 79 та $46 \%$ відповідно), що можна пояснити частковим окисленням цього тіолу. Супероксиддисмутазна активність за ГА була підвищена, загальна антиоксидантна активність та рівень карбонілювання протеїнів відповідали контролю, але каталазна та глутатіон-S-трансферазна активність і вміст глутатіону були нижчими на $28-44 \%$ порівняно 3 контролем, тоді як рівень пероксидного окислення ліпідів (ТБК-АП) - вищим на 59\%. Аналіз основних компонентів підтвердив сильний взаємозв'язок між МТ та індексами пе- роксидзалежного окисного стресу. Внаслідок дослідження виявлено молекулярні основи дисбалансу Zn під час гострого ГА як наслідку послаблення редокс-статусу клітинних тіолів, що дає можливість рекомендувати ці біомаркери для оцінки патологій колінного суглоба.

К л ю ч о в і с л о в а: гонартрит, металотіонеїни, цинк, окисний стрес.

\section{References}

1. Rice JM, Zweifach A, Lynes MA. Metallothionein regulates intracellular zinc signaling during CD4(+) T cell activation. BMC Immunol. 2016; 17(1): 13.

2. Krężel A, Maret W. The biological inorganic chemistry of zinc ions. Arch Biochem Biophys. 2016; 611: 3-19.

3. Frangos T, Maret W. Zinc and Cadmium in the Aetiology and Pathogenesis of Osteoarthritis and Rheumatoid Arthritis. Nutrients. 2020; 13(1): 53.

4. Sun J, Li L, Li L, Ding L, Liu X, Chen X, Zhang J, Qi X, Du J, Huang Z. Metallothionein-1 suppresses rheumatoid arthritis pathogenesis by shifting the Th17/Treg balance. Eur J Immunol. 2018; 48(9): 1550-1562.

5. Lespasio MJ, Piuzzi NS, Husni ME, Muschler GF, Guarino A, Mont MA. Knee Osteoarthritis: A Primer. Perm J. 2017; 21: 16-183.

6. Sur B, Kang S, Kim M, Oh S. Inhibition of Carrageenan/Kaolin-Induced Arthritis in Rats and of Inflammatory Cytokine Expressions in Human IL-1 $\beta$-Stimulated Fibroblast-like Synoviocytes by a Benzylideneacetophenone Derivative. Inflammation. 2019; 42(3): 928-936.

7. Viarengo A, Ponzano E, Dondero F, Fabbri R. A simple spectrophotometric method for metallothionein evaluation in marine organisms: an application to Mediterranean and Antarctic Molluscs. Mar Environ Res. 1997; 44(1): 69-84.

8. Suzuki KT. Purification of vertebrate metallothioneins. Methods Enzymol. 1991; 205: 252-263.

9. Wang J, Niu Y, Zhang C, Chen Y. A micro-plate colorimetric assay for rapid determination of trace zinc in animal feed, pet food and drinking water by ion masking and statistical partitioning correction. Food Chem. 2018; 245: 337-345.

10. Re R, Pellegrini N, Proteggente A, Pannala A, Yang M, Rice-Evans C. Antioxidant activity 
applying an improved ABTS radical cation decolorization assay. Free Radic Biol Med. 1999; 26(9-10): 1231-1237.

11. Beauchamp C, Fridovich I. Superoxide dismutase: improved assays and an assay applicable to acrylamide gels. Anal Biochem. 1971; 44(1): 276-287.

12. Aebi H, Bergmeyer HU. Catalase. Methods Enzym Anal. 1974; 2: 673-677.

13. Habig WH, Pabst MJ, Jakoby WB. Glutathione S-transferases. The first enzymatic step in mercapturic acid formation. J Biol Chem. 1974; 249(22): 7130-7139.

14. Griffith OW. Determination of glutathione and glutathione disulfide using glutathione reductase and 2-vinylpyridine. Anal Biochem. 1980; 106(1): 207-212.

15. Ohkawa H, Ohishi N, Yagi K. Assay for lipid peroxides in animal tissues by thiobarbituric acid reaction. Anal Biochem. 1979; 95(2): 351358.

16. Reznick AZ, Packer L. Oxidative damage to proteins: spectrophotometric method for carbonyl assay. Methods Enzymol. 1994; 233: 357-363.

17. Ellman GL, Courtney KD, Andres VJr, Featherstone RM. A new and rapid colorimetric determination of acetylcholinesterase activity. Biochem Pharmacol. 1961; 7: 88-95.

18. Khoma V, Gnatyshyna L, Martinyuk V, Mackiv T, Mishchenko L, Manusadžianas L, Stoliar O. Common and particular biochemical responses of Unio tumidus to herbicide, pharmaceuticals and their combined exposure with heating. Ecotoxicol Environ Saf. 2021; 208: 111695.

19. Lynes MA, Zaffut K, Unfricht DW, Marusov G, Samson JS, Yin X. The physiological roles of extracellular metallothionein. Exp Biol Med (Maywood). 2006; 231(9): 1548-1554.

20. Grider A, Cousins RJ. Role of metallothionein in copper and zinc metabolism: special reference to inflammatory conditions. In: Milanino R, Rainsford KD, Velo GP (Eds.). Copper and Zinc in Inflammation. Inflammation and Drug Therapy Series. Dordrecht, Springer 1989; 4: 2132.
21. Hwang J, Jin J, Jeon S, Moon SH, Park MY, Yum DY, Kim JH, Kang JE, Park MH, Kim EJ, Pan JG, Kwon O, Oh GT. SOD1 suppresses proinflammatory immune responses by protecting against oxidative stress in colitis. Redox Biol. 2020; 37: 101760.

22. Scott JL, Gabrielides C, Davidson RK, Swingler TE, Clark IM, Wallis GA, BootHandford RP, Kirkwood TBL, Taylor RW, Young DA. Superoxide dismutase downregulation in osteoarthritis progression and end-stage disease. Ann Rheum Dis. 2010; 69(8): 1502-1510.

23. García-González A, Gaxiola-Robles R, ZentenoSavín T. Oxidative stress in patients with rheumatoid arthritis. Rev Invest Clin. 2015; 67(1): 46-53.

24. Dunning DL, Holmes J, Gathercole SE. Does working memory training lead to generalized improvements in children with low working memory? A randomized controlled trial. Dev Sci. 2013; 16(6): 915-925.

25. Dröge W. Free radicals in the physiological control of cell function. Physiol Rev. 2002; 82(1): 47-95.

26. Rudyk O, Eaton P. Biochemical methods for monitoring protein thiol redox states in biological systems. Redox Biol. 2014; 2: 803-813.

27. Wang $\mathrm{Y}$, Weisenhorn $\mathrm{E}$, MacDiarmid CW, Andreini C, Bucci M, Taggart J, Banci L, Russell J, Coon JJ, Eide DJ. The cellular economy of the Saccharomyces cerevisiae zinc proteome. Metallomics. 2018; 10(12): 1755-1776.

28. Hoover DB. Cholinergic modulation of the immune system presents new approaches for treating inflammation. Pharmacol Ther. 2017; 179: 1-16.

29. Itoh Y. Metalloproteinases in Rheumatoid Arthritis: Potential Therapeutic Targets to Improve Current Therapies. Prog Mol Biol Transl Sci. 2017; 148: 327-338.

30. Won Y, Shin Y, Chun CH, Cho Y, Ha CW, Kim JH, Chun JS. Pleiotropic roles of metallothioneins as regulators of chondrocyte apoptosis and catabolic and anabolic pathways during osteoarthritis pathogenesis. Ann Rheum Dis. 2016; 75(11): 2045-2052. 